\title{
Development of a Local Regional Service Market in the Context of Transformational Economics
}

\author{
Vitaly Valerievich Janov \\ Volga Region State University of Service, 445000, Russia, Samarskaya obl., Togliatti, Gagarina str., 4
}

\section{Doi:10.5901/mjss.2015.v6n3s2p619}

\begin{abstract}
The article is dedicated to development of local service markets promoting the growth of a consumer market sphere which is one of the priority directions in the dynamics of regional economics indices. Traditional types of services are displaced by new ones, competition level growth can be constantly observed first of all in the spheres of health care, education, recreation and tourism, new forms and methods of servicing appear. Transition to development of local service markets contributed to the growth of the sphere of consumer market which at the present time occupies one of the priority directions in the dynamics of indices of regional economics.
\end{abstract}

Keywords: a service market, a local service market, a regional market, factors influencing a local market.

\section{Introduction}

Market-related transformations in economics promoted the growth of demand for consumer services which resulted in an unprecedented phenomenon in the Russian economics: an adequate reaction of the customer services supply to the demand for them. Market-related changes in the structure of the consumer amenities production allowed to get over the existing disproportion between the demand and supply in the services sector and ensured prerequisites for further promotion of the demand for consumer services, in addition operation of the local markets offering the said services began to reflect specific logic of market development in the conditions of transformational economics.

A local market as an objective reality and a structural component of a regional market has not yet received a scientific substantiation of its economic essence, of a mechanism of development and functioning as well as of the functions performed. The economic literature does not practically give any clear definition of this category. The publications contain only indirect references, for example "local markets are a market segment of a national economics distinguished by marketing, functional and other features" (Morozova, Pobedina \& Polyak, 2009); "local - located within a part of a province, in a city, a suburb, a region" (Granberg, 2004); "wholesale markets are predominantly of local nature (serve for small territories)" (Pchelintsev, 2004). The above allows the conclusion that at the present time there does exist a problem of theoretical substantiation of the "local markets" category.

The volume of consumer services is a derivative from an effective demand for services and their supply. The structure of local service markets is characterized by an important feature due to which a market ensures a long-term equilibrium between the demand for and the supply of the services. In the meantime the demand for the consumer services can not be equivalent to the supply since in the consumer services sector the quantity of services demanded always exceeds the quantity supplied. Such "non-satiation" of the demand with the consumer services is a specific Russian peculiarity of the post-administrative period of economy management which reflects social consequences of the socialistic principle of "socialized consumption" on a free-of-charge basis.

\section{Methodology}

For determination of the mentioned economic category the home and foreign literature dedicated to the market investigation makes use of various methodological approaches (See Table 1). 
Table 1. Theoretical approaches to interpretation of a concept of the category of "market"

\begin{tabular}{|c|c|c|c|c|c|}
\hline Approaches to $\begin{array}{c}\text { Authors } \\
\text { determination of market }\end{array}$ & $\begin{array}{l}\text { McConnell C. } \\
\text { Brue S. }\end{array}$ & Lipsits N.A. & $\begin{array}{l}\text { Chepurin M.N. } \\
\text { Kiselyova Y.A. }\end{array}$ & $\begin{array}{l}\text { Abalkin } \\
\text { A.I. }\end{array}$ & $\begin{array}{l}\text { Azriliyan } \\
\text { A.N. }\end{array}$ \\
\hline Institutional & $\begin{array}{l}\text { an institution or a } \\
\text { mechanism } \\
\text { bringing buyers } \\
\text { (producers of } \\
\text { demand) and } \\
\text { sellers (suppliers) } \\
\text { of individual } \\
\text { goods and } \\
\text { services in } \\
\text { contact }\end{array}$ & $\begin{array}{l}\text { an aggregate of } \\
\text { forms and } \\
\text { structures of } \\
\text { cooperation } \\
\text { between people } \\
\text { designed for } \\
\text { bringing sellers and } \\
\text { buyers together for } \\
\text { commercial } \\
\text { purposes and } \\
\text { giving the } \\
\text { opportunity to the } \\
\text { former to sell and } \\
\text { to the latter to buy } \\
\text { goods }\end{array}$ & & & \\
\hline Subjective & & & $\begin{array}{l}\text { interaction of } \\
\text { producers and } \\
\text { consumers } \\
\text { based on a } \\
\text { decentralized } \\
\text { mechanism of } \\
\text { price segments }\end{array}$ & & \\
\hline $\begin{array}{l}\text { Segmenta-tional approach to a } \\
\text { market functioning }\end{array}$ & & & & $\begin{array}{l}\text { abstract } \\
\text { or actual } \\
\text { space } \\
\text { where the } \\
\text { supply of } \\
\text { and the } \\
\text { demand } \\
\text { for } \\
\text { various } \\
\text { amenities } \\
\text { interact as } \\
\text { well as } \\
\text { the } \\
\text { method of } \\
\text { such } \\
\text { interaction }\end{array}$ & \\
\hline Substantive & & & & & $\begin{array}{l}\text { a system of } \\
\text { economic } \\
\text { relations } \\
\text { consisting in } \\
\text { sale and } \\
\text { purchase of } \\
\text { goods within } \\
\text { the } \\
\text { framework of } \\
\text { which the } \\
\text { demand for, } \\
\text { the supply of } \\
\text { and the price } \\
\text { of such } \\
\text { goods are } \\
\text { being formed }\end{array}$ \\
\hline
\end{tabular}

Therefore based on economic concept of the market notion the market should be treated as an aggregate of methods and terms of interaction between business units allowing to determine the ratio of demand for and supply of the various 
kinds of goods and services by means of a market pricing mechanism as well as to make commercial transactions. In this case the following conditions apply: atomistic nature of a market actor, freedom of entry into a market, mobility of production factors and market transparency ensuring provision of all necessary information to the interested business units.

The above conditions are common for development of any market type; adherence to them promotes development of a perfect market or a pure competitive market. Within the Russian Federation there can be distinguished a significant number of markets and features shaping the same. As was mentioned above a market size or its territorial coverage where regional and local markets are being distinguished within the boundaries of a national market is the most common criterion of classification. The economic literature contains references to a great number of criteria specific for a definite territory (economic specialization of a region, its geopolitical state, socioeconomic aspect of development) and features which form a regional market. At the same time there are various opinions as to determining a regional market as an economic category. Thus Grandberg A. defines a regional market as "a market of an individual region having distinctions both in location and types of goods present in it, prices, environment, demand for and supply of goods" (Granberg, 2007). In his monograph "Regional market: reproduction aspect" Arzhenovskiy I. investigates a regional market as a sphere of circulation of goods and services emphasizing at the same time that its functioning is "incompatible with in-kind exchange, demonstration of departmentalism since in such case a fundamental principle of a single economic space of a country is being contravened" (Fetisov \& Oreshin, 2006). According to other economists, namely Butov V., Ignatov V., Ketova N., a regional market should be determined as an aggregation of highly-localized socioeconomic processes and relationships in the sphere of circulation which are governed by specific features of demand and supply of every territorial and administrative unit with account of adequate methods of market environment regulation and decision-making (Fetisov \& Oreshin, 2006).

The interpretations of a regional market quoted above promote its unification since they can be applied to the market of any business unit of the Russian Federation. At the same time given the size of the RF territory each region has its own specialization in the national economics, unique economical and geographical location, natural and labor resources as well as traditional ways of production and consumption of specific kinds of products. The last statement allows coming to a conclusion that a set of important criteria which reflect specificity of an individual region and of the goods (services) produced in its territory were not covered by the existing definition of a regional market.

\section{Main Part}

The term of "local market" may be used for explanation of a concept of a regional market as an economical category allowing to take into account economical specialization, national peculiarities as well as traditional approaches to production and consumption of products in the territory of a constituent entity of the Russian Federation. The basis of the notion of local market may include both the features attributable to any of the markets but having specific value for the definition of local market and those which are characteristic only for this type of market. Such criteria may comprise:

- territorial belonging and limited character of a territory;

- product specialization;

- a mechanism of demand, supply and market environment;

- a market capacity and trade procedures (forms);

- freedom of market entry and composition of its actors;

- the level of prices and pricing mechanism;

- the state of infrastructure.

The modern economic system is characterized by the coexistence of the global, national, regional and local (domestic) markets and each of them operates in conjunction with other markets (Figure 1). Therefore special theoretical analysis of the problems of formation and functioning of a local market alone is a logical convention to a large extent beyond which again there is a single market with a single mechanism of formation and functioning (Kvint,2009). Coexistence of the global and local markets, analysis of their nature and dynamics of development as well as understanding by the economic entities acting in the local market which market is supposed to be used as a place for products realization is of paramount importance for elaboration of strategies aimed at improvement consumer-oriented properties of the services provided by the said actors. 


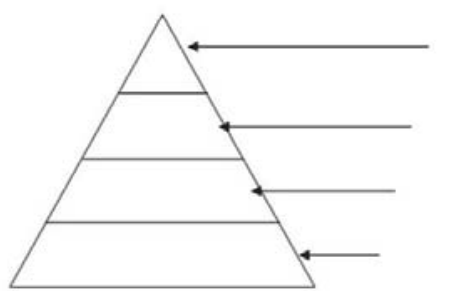

\author{
Local level \\ Regional level \\ National level \\ Global level
}

Figure 1. Multilevel architectonics of the global consumer services market

The global market is first of all a market of free (interregional and interstate) circulation of goods, services and labor. Consequently the process of globalization of the national economy accelerates formation of free economic zones thus resulting in saturation of the market with various goods of the same intended purpose (Andy, 2006). Financial capacity of the global market allows to forward constantly growing material resources and funds for creation of new products. Finally, the concentration of capital and the possibility of increasing investment in brand new products and services become one of the decisive factors of competitiveness in the global market.

Notwithstanding all of the advantages of the global market its main advantage, i.e. a global nature of formation and functioning in some situations turns into its opposite interfering achievement of efficiency required for the global market participants. This disadvantageous side of the global market (which does not exist in the local market) is connected with the enlarged number of links in the structure "producer - consumer", i.e. elongation of the supply chain starting from raw materials and ending with final product sale, and as a result growth of rate of negative financial consequences in case of the chain breakage (McCann, 2001). This primarily relates to supply of technical products the complexity and cost of which in recent decades has a tendency to increase. In this case, a defect of an element or use of another component with the cost of a few rubles can result in refusal of the final consumer from the products costing hundreds of thousands and millions of rubles, for the losses from such defects increase exponentially with increase of the distance from the place of their origin. In this situation the greatest losses will be incurred by the economic entities whose business is related to production or use of final products. Therefore the market globalization brings about a need for increased responsibility in the supply chain as well as the elaboration of measures ensuring involvement of reliable and stable operating suppliers. In this situation it is easy to understand for example the tendency within the international community to establish specific standards for quality systems that must function in the enterprises supplying their products to the world markets, as well as to elaborate own rigid certification of such quality systems. It is also important that tough competition acts as the global market mechanism of natural selection and such criteria as quality, price, observance of delivery deadlines and supplier reliability are the main parameters of competitiveness. The preference will be given to the manufacturing enterprise with such consumer services management which ensures an acceptable level of quality and price. It's worth noting that both the demand and the supply in a local consumer services market are being defined not only by economic factors but also are influenced by local traditions and by natural and climatic and demographic characteristics of a region (see Table 2).

Table 2. Factors determining demand and supply in a local market of consumer services.

\begin{tabular}{|l|l|l|}
\hline \multirow{2}{*}{$\begin{array}{l}\text { Factors determining demand } \\
\text { and supply in a local market }\end{array}$} & \multicolumn{1}{|c|}{ Consumer services in a local market } \\
\cline { 2 - 3 } Economic & \multicolumn{1}{|c|}{ Demand } & \multicolumn{1}{c|}{ Supply } \\
\hline Social & $\begin{array}{l}\text { Price of consumer services in a region } \\
\text { Personal income behavior } \\
\text { Degree of demand elasticity depending on } \\
\text { price and income } \\
\text { Availability and quality of substituting goods }\end{array}$ & $\begin{array}{l}\text { Taxation and credit mechanism } \\
\text { Equipment depreciation } \\
\text { Investment climate } \\
\text { Resource and technological state of a region } \\
\text { Competitiveness } \\
\text { Economic interrelationships with suppliers and consumers }\end{array}$ \\
\hline Demographic, natural and \\
climatic & $\begin{array}{l}\text { Educational level in a region } \\
\text { Professional training } \\
\text { Human resources } \\
\text { Regional mentality }\end{array}$ & $\begin{array}{l}\text { Number and structure of population } \\
\text { Quality of life } \\
\text { Status of institutions in social sphere } \\
\text { Content and level of socioeconomic development of a region }\end{array}$ \\
\hline $\begin{array}{l}\text { Natural population growth in a region } \\
\text { Migration policy } \\
\text { Formation of traditions and norms of } \\
\text { demographic behavior of population }\end{array}$ & $\begin{array}{l}\text { Population displacement policy } \\
\text { Occupational structure indices } \\
\text { Environmental management quality }\end{array}$ \\
\hline
\end{tabular}


The global and local markets do not exist in isolation from each other. Any economic region combines the features of the global and local markets in some specific ratio (Kwoka \& Lawrence, 2003). The mentioned ratios depend on particular character of product orientation which defines differentiation between the local markets, therefore the structure of demand and supply in such markets will be presented by production and consumption of goods and services having different quality level. For economic entities acting in a local market information about the structure of consumer services quality is particularly necessary for formation of an effective segment of the regional economy.

The current level of development of market relations in the Russian economy inclusive of the sphere of the consumer market allows coming to a conclusion that the relevant market in Russia has been almost formed. Nevertheless the efficiency of functioning of the consumer services market in the Russian economy is far from being uniform, which is the result of both objective and subjective factors most of which belong to the sphere of functioning of the main reproductive elements, i.e. the labor market, the price of labor power, the demand for and supply of products and services, the competitive mechanisms (Capello, 2006). Economic estimate of functioning of any local market (inclusive the local consumer services market) is determined first of all by the properties of its "market" location which ensures the possibility of realization of its various functions. The variants of development of a local regional consumer services market suppose distinguishing and fixing of the set values of the relevant local market parameters which include: the number of enterprises which produce consumer services in the region and the policy of product structure diversification implemented by them; evaluation of the local consumer services market capacity; segmentation of the local consumer services market by the level of the services specialization; determination of real and potential boundaries of the local consumer services market within a definite region; competitive environment (mapping of location of the competing consumer services producers within a certain local market with specification the limits of their scope of activity, determining a share of a customer base falling on the competing entities for each segment).

\section{Findings}

Therefore it is advisable to take the following aspects as assumptions for construction of a model of local consumer services market:

- a supply price of a consumer product or service in a local market has a dominant effect on such market;

- formation of a demand for consumer goods and services produced by public and commercial enterprises which would be stable by value and structure;

- fluctuations in the volume of consumer goods and services for each segment of the corresponding local market is due to the movement of consumer goods and services from one segment to another under the influence of the price difference in the filed of their supply;

- change in the conditions of sale of consumer goods and services within a local market is not accompanied by the movement of consumer preferences into new segments of the market (or such movement is negligible).

\section{Conclusion}

Characteristic features of development and functioning of a local service market as distinguished in the course of this investigation enable setting the market definition. A local market should be understood as a part of regional market within which certain products (service) or one group of products are realized (provided that the products or services have definite features and are produced on the territory of a specific region) and which reflects geopolitical location and economic specialization and is characterized by maximum approximation of a producer and a consumer. Its efficient functioning is ensured by an infrastructure, a stable pricing mechanism which depends on the specificity of demand and supply of the participating entities, freedom of entry to the market with changeable market environment. However formation of a local service market at the meso level has not been yet fully provided with the methodological principles and procedural tools for each region has its own inherent model of socio-economic development. As a consequence the traditional approach uses fragmentary description of the possibilities of a region in relation to development of a local service market as well as inadequate semantic presentation. Actual practice requires further development of the theory and methodology of forming a local service market, finding effective methods and development tools and of making decisions regarding its functioning.

\section{References}

Andy, P. (2006). Local and Regional Development. New York, London: Routledge. 
Capello, R. (2006). Regional Economics (Routledge Advanced Texts in Economics and Finance). New York, London: Routledge. Fetisov, G.G., \& Oreshin, V.P. (2006). Regional economics and management: textbook. Moskow: INFRA-M (In Russian).

Granberg, A.G. (2007). Modeling of special development of national and global economics: evolution of approaches. Region: ekonomika i sotsiologiya, 1, 87-107 (In Russian).

Strategies of macroregions in Russia: methodological approaches, priorities and ways of implementation. (2004). A.G. Granberg (Ed.). Moscow: Nauka (In Russian).

Kvint, V.L. (2009). The Global Emerging Market. Strategic Management and Economics. New York, London: Routledge.

Kwoka, J. E. Jr., \& Lawrence, J. W. (2003). The Antitrust Revolution: Economics, Competition, and Policy. Oxford: Oxford University Press.

McCann, P. (2001). Urban and Regional Economics. Oxford: Oxford University Press.

Morozova, T., Pobedina, M., \& Polyak, G. (2009). Regional economics: Textbook. Moscow: Unity-Dana (In Russian).

Pchelintsev, O.S. (2004). Regional economics within the system of sustainable development: textbook for higher educational institutions. Moscow: Nauka (In Russian). 